\title{
Forms of address in Basque
}

\author{
Xabier Alberdi-Larizgoitia \\ University of the Basque Country (UPV/EHU)
}

The aim of this article is twofold: first, to analyze and characterize forms of address in present-day Basque from a linguistic and sociolinguistic point of view, and, second, to underscore some of the distinctive features that make Basque interesting with regard to address.

This work characterizes forms and systems of address in Basque based on two main factors: second-person pronouns and allocutivity. Five types are proposed depending on dialectal variety, and the existing differences in each of these systems are described. This article aims to fill a gap in Basque studies by analyzing modes of address in present-day Basque as a whole and going beyond mere grammatical analysis: previous studies are rather partial and confusing in terms of linguistic description, dialectal distribution and social usage (hierarchy among modes of address); in contrast, this article, based on extensive field work, gives an account of the different address systems according to the dialect and shows the sociopragmatic value (i.e., level of formality or politeness and personal distance) that each mode of address acquires in its system.

The article will also highlight some of the distinctive linguistic features that make Basque interesting with regard to address. Forms of address in Basque display strong similarities with those in other languages in terms of the pronominal system and its historical development, yet they also show some distinctive features, namely: verbal allocutivity, which presents the speaker-hearer axis; gender differences in verb forms for familiar address; and the grammaticalization of expressive palatalization in the case of the $x u$ form of address ( $x u$ being an expressive variant of the polite pronoun $z u$ ). Current trends towards simplification of the systems of address are also discussed, as is the existence of groups of speakers who use a simplified system.

Keywords: address, forms of address, linguistic politeness, allocutivity, Basque 


\section{Introduction}

Since the publication of Brown and Gilman's (1960) seminal work, studies of forms of address and their evolution have witnessed a great blossoming. A productive area of research has opened up in many languages concerning forms of address and sociolinguistic variables that account for the use of pronouns of address (Braun et al. 1986; Fernández and Gerhalter 2017). However, there have been few studies concerning forms and systems of address in Basque and their use from a viewpoint transcending mere grammatical analysis.

It is evident that forms of address are social deictic expressions that put language and society in relation to each other. Politeness manifests itself through the different forms of address; and the variation in the forms of address depends on interpersonal relationships and questions of power and solidarity (Brown and Gilman 1960). According to Brown and Levinson $(1987,15)$, the level of verbal politeness to be used to ensure the adequate maintenance of social relationships depends on three main factors: the relative power of a speaker over another; the social distance existing between them, which conforms to the "frequency of interaction and the kind of material or non-material goods (including face) exchanged"; and the ranking of the imposition of the threatening act, which must be updated in each specific situation. According to this theory, the selection of one form of address or another must take into account these three broad factors, ${ }^{1}$ and their use is always aimed at safeguarding one's own face and that of the interlocutor, through social rules in force in each community of speakers. Consequently, forms and modes of address are part of social deixis since they are grammatical elements that codify the established social relationship between the participants in communicative interaction (Brown and Levinson 1987, 179).

Previous studies about address in Basque are rather partial and confusing in terms of dialectal distribution and social usage, and do not analyze the problem of address as a whole; thus, this article offers a global linguistic analysis, which gives an account of the different address systems according to the dialect and the sociopragmatic value (i.e., level of formality or politeness and personal distance) that each mode of address acquires in its system. This article aims to fill that gap by analyzing modes of address in present-day ${ }^{2}$ Basque from a formal, dialectological

1. These three factors are composite categories which consist of culturally specific factors.

2. The data of this study was collected in the 1990s (and the Ph.D. was published in 1994); so, this article reflects the different dialectal systems of address and the social patterns and main sociolinguistic variables governing the use of forms of address at this stage in the Basque language: the mid-nineties. 
and sociolinguistic point of view: we will analyze the most relevant sociolinguistic variables that condition their use.

The article will also highlight some of the distinctive linguistic features that make Basque interesting with regard to address. Previous studies on this topic in Basque linguistics only provide a rough and confusing picture of its modes of address and their dialectal diversity. One of the distinctive features of some of these modes is allocutivity (see Section 3.2), i.e. codification by means of a person marker of the listener in conjugated verb forms whose arguments do not include the listener (Hualde \& Ortiz de Urbina 2003). In early descriptions of the allocutive mode in eastern dialects (Bonaparte 1869; Azkue 1923), the sociopragmatic value of the opposition between allocutive and non-allocutive modes is not clarified. In more recent studies (Rebuschi 1984), allocutivity is discussed when characterizing the modes of address, but the rules described do not adequately reflect the dialectal reality of eastern dialects (cf. Section 3.4.3). Still more recently Oyharçabal (1993), studying allocutivity from a formal point of view, has proposed to distinguish between allocutivity (a grammatical agreement phenomenon) and mode of address. This article, taking that distinction as its basis, analyzes the potential sociopragmatic value of allocutivity, illustrating the different modes of address in Basque dialects. In addition to characterizing the different modes of address in Basque (Section 3.4), this article notes similarities between Basque and Indo-European languages, while also pointing out the specific areas where they diverge.

First some basic points about Basque will be reviewed in order to put the analysis into perspective. Basque, a non-Indo-European language spoken in the Basque Country, currently has about 700,000 speakers located on either side of the Spanish-French border. Those on the Spanish side live in either the Basque Autonomous Community (BAC) or the Autonomous Community of Navarre, while the French side covers the historical regions of Labourd (Lapurdi in Basque), Low Navarre, and Soule (Zuberoa). Legally Basque has "co-official" status (alongside Spanish) in the BAC and in a designated "Basque speaking area" in Navarre, and no official status in the French Basque Country.

Basque is characterized by a considerable dispersion between dialects, and standardization is recent. The foundation of a Unified Basque was laid in 1968 (Salaburu \& Alberdi 2012). Between 1968 and 1990, following unification and the granting of official status, Basque found its way into new domains in education, administration and mass media for the first time ever, which within the Spanish-Basque area has led to rapid development of the language in new functions and an increase in the number of speakers in new generations. This increase in the southern area contrasts with a steady decrease of speakers in the French Basque Country, attributable in part to the lack of any official recognition for the language. 
For centuries past, Basque has been co-existing with two hegemonic languages (Spanish and French); today it still remains a minority language. Despite efforts to attain balanced bilingualism, only a minority of the population is bilingual. According to the 2011 survey (Basque Autonomous Community 2013), 27\% of the population aged 16 and over in the Basque Country is bilingual: $32 \%$ in the BAC; $11.7 \%$ in Navarre; and $21.4 \%$ in the Northern Basque Country. In recent decades, the number of bilingual speakers in the BAC has risen by more than $15 \%$, mainly among young people thanks to linguistic policies that give prominence to bilingual (Basque/Spanish) or monolingual (Basque only) models in education.

The degree of dispersion of Basque dialects may be attributed largely to the abruptness of the terrain in conjunction with the absence of a standard variety and the denial of official status until recently. According to Michelena (1981), since the Early Middle Ages dialectal dispersion underwent a steady increase from a more or less unified variety. Up to not long ago, the authoritative classification of dialects was that of Bonaparte $(1863,1869)$, who distinguishes the following dialects from west to east: Bizkaian, Gipuzkoan, Lapurdian, High Navarrese, Low Navarrese, Zuberoan and the extinct Erronkari dialect. Recently, Zuazo (1998) has proposed a different classification, which we will follow in this article: Western (including not only the Basque spoken in Bizkaia, but also that of Araba and the west of Gipuzkoa), Central (Gipuzkoan), Lapurdian-Navarrese (spoken in Lapurdi and Low Navarre), High Navarrese, Zuberoan and Eastern Navarrese (spoken in the Zaraitzu and Erronkari valleys)

\section{Methodology}

This study is partly based on the results of a doctoral thesis (Alberdi 1994) on the use of modes of address in Basque. The data were collected through a structured dialogue questionnaire with 210 adult respondents (112 men and 98 women). One of the study's objectives was to investigate the dialectal spread of each mode of address and of the various dialectal systems of address in Basque. To that end, the 210 interviews were carried out in 50 villages and towns representing different dialects and varieties according to Bonaparte's (1869) classification, as follows: Bizkaian, 44 interviews; Gipuzkoan, 30; Northern High Navarrese, 26; Southern High Navarrese, 1; Aezkoan, 1; Zaraitzu dialect, 1; Gipuzkoan, 17; Western Low Navarrese, 12; Eastern Low Navarrese, 49; Zuberoan, 29. The main aim of the fieldwork was to shed light on questions about the dialectal distribution and sociopragmatic value of each of the modes of address, depending on the dialect.

Other aspects related to the use of modes of address were also considered, and additional independent variables other than dialect (sex, age and rural or urban 
origin) were taken into account when compiling the sample. Since the present article aims to analyze systems of address in Basque, those variables are briefly examined in Section 3.3, and the rules of address are scrutinized according to dialectal variety, comparing their particularities and similarities to systems in other languages.

\section{Findings and discussion}

\subsection{Forms of address in the pronominal system of Basque}

Strictly speaking, Basque only has first and second person personal pronouns. From a cross-dialectal perspective, the following pronouns for the second person are distinguished:

Table 1. Second-person pronouns (Basque)

\begin{tabular}{ll}
\hline Singular & $\begin{array}{l}\text { Plural } \\
\text { II (person referential) }\end{array}$ \\
\hline$h i$ & II' (person referential plural) \\
\hline$z u$ & \\
\hline
\end{tabular}

As Table 1 shows, there are two personal pronouns to address one person: $h i(\mathrm{~T})$ connotes closeness; $z u$ connotes politeness. Everything suggests that the present-day singular polite form (V: $z u$ ) was an original plural that underwent a development similar to that in many other languages, including Spanish, French and many other Indo-European languages (Joseph 1987).

This shared historical system is subject to dialectal complications. In southern dialects (Table 2) an innovation is added: a pronominal form of "hyper-politeness" or "deference", berori, which is used with third-person singular verb forms. This pronoun is used to address priests and very prominent persons; it entails asymmetry. This is somewhat reminiscent of the forms vuestra merced, vuestra señoría, vuestra excelencia, etc. introduced in Spanish in the thirteenth to sixteenth centuries (Lapesa 1970; Moreno 2002). Significantly, the Basque innovation (Alberdi 1995) is restricted to the Spanish Basque area but has not extended to Basque as spoken in France. ${ }^{3}$

3. The southern system of address is "mixed" (Joseph 1987: 262) because historically, as in Indo-European languages (Head 1978), number shift (use of the plural form as singular) occurs first for show deference, and recourse to person shift (from second to third person) comes later. 
Table 2. Second-person pronouns: Southern Basque

\begin{tabular}{ll}
\hline II (singular) & II' (plural) \\
\hline hi & zuek \\
\hline$z u$ & $\begin{array}{l}\text { beroriek } \\
\text { (variants: beroriek, berok, eurok) }\end{array}$ \\
\hline berori & (vel
\end{tabular}

There are a few points to be noted about the "deferential" pronoun berori. First, the opposition "singular (berori) / plural (beroriek)" seems to point to a previous stage of the language, since the plural is found in writings by both Bizkaian authors (using the variant eurok) and Gipuzkoan writers (with the variant berok) down to the nineteenth and the early twentieth century. Secondly, all the evidence gathered in the course of our research (interviews and the present-day literary corpus) ${ }^{4}$ hints at the obsolescence of the pronoun berori, which is now no more than a vestige of a previous stage of the language and only used by elderly speakers. ${ }^{5}$

For the most part, the pronominal address system of northern Basque dialects is conservative (Table 1, repeated here as Table 3 ).

Table 3. Second-person pronouns: Northern Basque

\begin{tabular}{|c|c|}
\hline II (singular) & II' (plural) $^{\prime}$ \\
\hline$\overline{h i}$ & zuek \\
\hline$\overline{z u}$ & \\
\hline
\end{tabular}

Furthermore, to the north of the Spanish-French border, in the eastern part of the Lapurdian-Navarrese dialect (areas of Low Navarre, Aturri) and in Aezkoa and Zaraitzu south of the border, a palatalized pronominal variant $x u$ is found. This is historically more recent and represents an intermediate social level in the pronominal address system: it is principally used to address a woman, a young child (regardless of gender) and family members in general (Sections 3.4.2 and 3.4.3).

4. As we can see in the corpus Ereduzko Prosa Gaur (Contemporary Reference Prose), most of the times when berori has been used in literary works, it appears in translations of ancient texts (Don Quixote, Hamlet...) to translate a deferential ancient address form (for instance, Spanish vuestra merced). http://www.ehu.eus/en/web/eins/ereduzko-prosa-gaur-epg- [2017-07-07].

5. This system distinguishes three forms in the singular and two forms in the plural, and resembles Catalan (II: $t u<$ vós < vostè; II': vosaltres-vostès). In any case, the deferential form (berori) is currently close to extinction, probably as a result of the asymmetry it entails, which in turn distinguishes it from pronouns that indicate hyper-politeness in other languages (Catalan: voste; Romanian: dumneavoastră; Spanish in some areas of America: usted; etc.). 
Table 4. Second-person pronouns: Lapurdian-Navarrese dialect, eastern area*

\begin{tabular}{ll}
\hline II (singular) & II' (plural) \\
\hline$h i$ & $z u e k$ \\
\hline$x u$ & \\
\hline$z u$ & \\
\hline
\end{tabular}

* This system resembles that of Spanish as spoken in many areas of America (Páez Urdaneta 1981; Hummel et al. 2010), which has preserved the use of tutoiement and vouvoiement (II: $t u<$ vos < usted; II': ustedes), with the special feature of an additional intermediate mode of address $(x u)$ derived from expressive palatalization of the polite pronoun $(z u)$.

Two important observations must be made regarding the current use of the main pronouns of address. In the first place, due to the obsolescence of the opposition berori/beroriek (Table 2), the distinctions of address that appear in the singular are neutralized in the plural, where there is only one form, zuek. Second, in all dialect varieties there are speakers who do not use the familiarity pronoun of address hi (a mode of address commonly referred to as hitano). This can happen as a result of either a lack of familiarity with the corresponding inflected verb forms or the loss of this mode of address in the speaker's local variety. ${ }^{6}$ As a consequence (Section 3.4.4), in most dialects we may find specific groups of speakers who have simpler systems of address (Tables $2^{\prime}, 3^{\prime}, 4^{\prime}$ ), while a substantial number only use the polite form $z u$.

Table 2'. Simplified subsystems of pronominal address in southern Basque

\begin{tabular}{llllll}
\hline 2.a & 2.b & \multicolumn{3}{c}{ 2.c } \\
\hline hi & $z u e k$ & $\frac{z u}{z u}$ & $\begin{array}{l}\text { zuek } \\
\text { (beroriek) }\end{array}$ & $z u$ & zuek \\
\cline { 3 - 5 } & & berori & & \\
\hline
\end{tabular}

Table 3'. Simplified subsystem of pronominal address in northern Basque

\begin{tabular}{ll}
\hline 3.a & \\
\hline$z u \quad z u e k$ \\
\hline
\end{tabular}

6. This lack of familiarity or mastery of the familiar form of address often occurs among native speakers, either because $h i$ is regressing in that area or because its use is restricted to certain circles (eg, among elderly people or outside the family). There are cases, for example, where the parents have not passed down the familiar mode of address to their children, although the parents use it with some people of their own age (old friends, siblings, etc.). 
Table 4'. Simplified subsystem of pronominal address: Eastern area of the Lapurdian Navarrese dialect

\begin{tabular}{ll}
\hline 4.a & \\
\hline$x u$ & zuek \\
\hline$z u$ & \\
\hline
\end{tabular}

\subsection{Allocutive verbal agreement}

In Basque, the verb agrees in person, number and case with verbal arguments (subject, object and dative). The choice of pronoun of address (hi, zu, berori or $x u$ ) is necessarily reflected through agreement in the verbal morpheme corresponding to the absolutive (1), ergative (2) and dative (3). In the $h i$ mode, a gender based distinction ${ }^{7}$ is made depending on the sex of the addressee; the distinction appears in ergative and dative morphemes $(2 \mathrm{a} / 2 \mathrm{~b})$, where the masculine suffix $-k$ contrasts with the feminine suffix $-n$.

(1) berori $\underline{\text { d-ator }}$

Deferential you-A 3sGA-come

'You [respectful] come'

(2) a. hi-k d-auka- $\underline{k}$

Familiar you-E 3sGA-have-2sGEMASC

'You [man] have'

b. hi-k d-auka-n

Familiar you-E 3sGA-have-2sGEFEM

'You [woman] have'

(3) $z u$-ri d-atorki-zu

Formal you-D 3sG-come-2sGD

'He/she/it comes to you'

Except for the gender distinction in the hi mode, this type of agreement with verbal arguments is somewhat similar to what is observed in many other languages.

7. The gender distinction in second-person familiar ( $h i$ ) verb forms (Lafon 1943, 1947, 1951, $1957,1959)$ is another notable feature of Basque. If the person marker of the verb corresponds to the second person argument $h i$, it is ergative or dative (unless realized by a prefix) and the addressee's gender is specified: $-k$ is used for masculine and $-n$ for feminine (see examples (2a) and (2b)). Gender differentiation (through the $-k /-n$ alternation) extends to all allocutive forms used in familiar address mode. 
But in the Basque verb phrase another morpheme is sometimes found that does not correspond to any of the arguments of the verb but to an addressee who is not an argument. This phenomenon, called allocutive agreement or allocutivity (Oyharçabal 1993), signals the "honorific" status of such sentences.

As explained before (Section 3.1), in some Basque dialects there are three pronouns for the second singular person "you". These forms differ in their degree of formality: $z u$ (formal or polite), $h i$ (informal), $x u$ (intermediate level, not formal or informal).

These three pronouns are inflected for case: absolutive, ergative and dative. In addition, the verb or auxiliary also takes morphemes which refer to the verb arguments (absolutive, ergative, dative) in all dialects of Basque including standard Basque.

In the dialects with an allocutive mode of address, the speaker may express his/ her relationship with the addressee - whether it is informal, formal or intermediate - by adding the corresponding morpheme on the verb or auxiliary (informal: $-k /-n$; formal: $z u$; intermediate: $-x u$ ).

For example, if the speaker is talking to a friend, he/she will add the morpheme $-k$ on the auxiliary for a male addressee and $-n$ for a female addressee (informal); $-z u$ for a formal relationship; $-x u$ (corresponding to the "intermediate" address) or "nothing" if the speaker wants to be neutral. These are the allocutive morphemes.

Thus, those allocutive morphemes $(-k /-n,-z u,-x u)$ refer to the relationship between the speaker and the addressee and they do not code the obligatory information on the verb arguments (absolutive, dative, ergative): some other morphemes will be added to the verb or auxiliary to code that information.

Allocutive agreement gives rise to an allocutive paradigm ${ }^{8}$ in which first and third person verb forms are modified. ${ }^{9}$ For instance, as shown in Table 5, the verb "to be" has its own allocutive forms. For example (see (4a)-(e) below), the form naiz is the neutral (-allocutive) first-person singular verb form meaning "am" (for "I am"). If I told someone: polita naiz ("I am beautiful"), no information on my relationship with my addressee would be provided (-allocutive). If I wanted to tell a female friend of mine that I thought I was beautiful and wanted to code my relationship with her (+allocutive), I would say polita nauN. If I were talking to a

8. See Alberdi (1995) about the development of the Basque system of terms of address.

9. We should also note that verb forms which select the second person as an argument are neutral regarding the allocutive/non-allocutive opposition. A distinction can thus be made among three types of verb forms (Lafon 1959, 106; Oyharçabal 1993): (i) allocutive forms, which show agreement with an allocutive second person (i.e. nauk/n "I am, alloc.", duk/n "she/he/it is, alloc."), (ii) neutral forms, without such agreement (naiz "I am", da "she/he/it is"), and (iii) those verb forms that agree with a second-person argument (haiz "thou art", zarete "you-pl are"). 
male friend I would say polita nauK. If I were talking to a professor I would not add the morpheme $-k /-n$ (-allocutive: naiz).

In second person forms (whether singular or plural), the addressee is a real argument so these forms do not participate in the +allocutive/-allocutive opposition, whereas first and third person non-allocutive or default verb forms (given in parentheses) are obligatorily replaced by corresponding allocutive forms (in capitals) in non-default modes of address.

Table 5. To be, present-tense paradigm in masculine/feminine familiar address (hi or hitano)

\begin{tabular}{|c|c|c|c|}
\hline PERSON & -ALlOcutive & +ALlOCUTIVE & 2ND PERSON ARGUMENT \\
\hline 1. & $\begin{array}{l}(\text { naiz })^{\star}-----> \\
\text { "am" }\end{array}$ & NAUK/NAUN & \\
\hline 2. & & & $\begin{array}{l}\text { haiz } \\
\text { "[you] are" }\end{array}$ \\
\hline 3. & $\begin{array}{l}(d a)---->> \\
\text { "is" }\end{array}$ & $D U K / D U N$ & \\
\hline $1 \mathrm{pl}$ & $\begin{array}{l}\text { (gara) -----> } \\
\text { "[we] are" }\end{array}$ & GAITUK/GAITUN & \\
\hline $2 \mathrm{pl}$ & & & $\begin{array}{l}\text { zarete } \\
\text { "[you] are" }\end{array}$ \\
\hline $3 \mathrm{pl}$ & $\begin{array}{l}(\text { dira })---->> \\
\text { "[they] are" }\end{array}$ & DITUK/DITUN/ & \\
\hline
\end{tabular}

\footnotetext{
* The parentheses and the arrow indicate that in familiar address ( $h i)$ non-allocutive verb forms must be replaced by corresponding allocutive forms.
}

So, the conjugated verb in (4a) which corresponds to the neutral or "default" form of address will be modified to incorporate different allocutive morphemes depending on the mode chosen for addressing the interlocutor $(h i, z u, x u)$. Examples (4b) and (4c) signal tutoiement (informal address) directed to a man or a woman respectively; (4d) signals vouvoiement, the allocutive $z u$ mode of formal address; (4e) signals the allocutive $x u$ mode of address. ${ }^{10}$

10. The $x u$ allocative form of address of eastern Lapurdian-Navarrese is also a distinctive feature of Basque address patterns. The palatalization of the courtesy pronoun $(z u>x u)$ is a phonological resource (Michelena 1961) that patterns with other cases of expressive palatalization of sibilant consonants. The peculiarity lies in the grammaticalization of the aforementioned phonological resource as an identifier of the mode of address, since it extends to all verb forms (both allocutive ones and those in which the addressee is an argument) in which a $x u$ pronominal marker appears. 
(4) a. Ni polita n-aiz

I-A beautiful am [1sGA-to be]

"I am beautiful" ["default" mode of address]

b. Ni polita $n-a u-\underline{k}$

I-A beautiful am [1sGA-to be-AAmAsc]

"I am beautiful" [tutoiement addressed to a man]

c. Ni polita $n-a u-\underline{n}$

I-A beautiful am [1sGA-to be-AAFEM]

"I am beautiful" [tutoiement addressed to a woman]

d. Ni polita n-au-zu

I-A beautiful am [1sGA-to be-AAzu]

"I am beautiful" [vouvoiement (allocutive $z u$ mode)]

e. Ni polita $n-a u-\underline{x u}$

I-A beautiful am [1sGA-to be-AAxu]

"I am beautiful" [vouvoiement (allocutive $x u$ mode)]

In some Romance languages such as French or Galician, allocutive dative clitics (Je TE lui ai écrit une note) may be used as relatively marked forms (Oyharçabal 1993): it is up to the speaker to use that dative clitic; in other words, it is not compulsory. In Basque, in contrast, allocutive agreement is required by the pronoun selected (and the dialect): (4a) (without any allocutive agreement) is unacceptable if uttered to an addressee who has been assigned the $h i$ mode of address.

A person who hears utterance (4b), then, receives two kinds of information: that derived from the proposition "I am beautiful" and that based on the allocutive agreement which signals masculine tutoiement, conveying the information that the addressee of this utterance is male and has been assigned the hi mode. In Basque Linguistics this phenomenon has been called "traitement allocutive" (allocutive address) (Bonaparte 1869), or "familiar voice" (Lafitte 1944) in the case of the $h i$ mode; it has been widely studied (Lafon 1957, 1959; Rebuschi 1984; Alberdi 1996).

In allocutive forms, the conjugated verb agrees in person (and in the hi mode also in gender) with the interlocutor even though the latter is not an argument selected by the verb. In examples $(4 b-4 e)$ the interlocutor does not intervene in the action referred to, is unrelated to any of the verb's arguments and has no part in the action either as a beneficiary or a disadvantaged party (Oyharçabal 1993).

The morphologization of modes of address makes Basque typologically interesting. This phenomenon is reminiscent of certain eastern languages (Japanese, Korean), where levels of language are established based on the addressee.

Comrie (1976) suggests that there are three types of honorifics, which can be categorized according to the axis on which they are constructed: 
a. the speaker-addressee axis: the relation of speaker to hearer (addressee honorifics),

b. the speaker-referent axis: the relation of speaker to things or persons referred to (referent honorifics),

c. the speaker-bystander axis: the relation of speaker (or hearer) to "bystanders" or overhearers (bystander honorifics).

Comrie argues that traditional descriptions have confused "addressee honorifics" and "referent honorifics", and cites Japanese and Javanese 'speech levels' as examples of "addressee honorifics". Comrie examines examples of "referent honorifics", citing the language used with mothers-in-law in Dyirbal (a code used in the presence of family members who are considered taboo) as an example of "bystander honorifics".

Unexpectedly, Comrie cites the well-known pronominal and verbal T/V alternation of European languages as a case of "referent honorifics" rather than "addressee honorifics". In European systems of the T/V type, as in all systems based on the speaker-referent axis, it is not possible to express respect towards the addressee without referring to him or her, unlike "speech levels" in languages from South Asia (Brown \& Levinson 1987, 180).

According to the theory of the three axes and Comrie's three types of honorifics, Basque stands out from its neighbors because through its modes of address, it allows its speakers to express respect, familiarity or trust towards an addressee without any need to make the addressee a referent. That does not mean, however, that allocutive modes of address in Basque are similar to the "speech levels" of eastern languages such as Japanese. In Japanese, pronouns of address and speech levels are autonomous, although they do have some sort of relationship; ${ }^{11}$ in Basque, the pronoun $(h i, z u, x u)$ selected to refer to the addressee is part of the system of grammatical agreement and is correspondingly marked on the allocutive verb.

Thus, on the one hand, the rules of address in Basque are similar to those in many European languages in that they are based on pronouns of address (T/V) and on the speaker-referent axis. On the other hand, they are in some ways analogous to the systems of address of eastern languages such as Japanese in that they introduce the speaker-addressee axis through the use of an allocutive verb.

11. In Japanese it is common to avoid pronouns, as they can be omitted; but speakers must choose a speech level according to the speaker-hearer axis and to the speaker-reference axis (Gardner \& Martin 1952). 


\subsection{Address in Basque: Main sociolinguistic variables}

The discussion in this section is based on data gathered in the mid-nineties, and given the development of the bilingual population in recent years and the current trend towards simplification of the systems of address (Section 3.4.4), it is reasonable to think that address forms and usage patterns of address might have undergone changes since then. On the one hand, it is probable that there have been quantitative changes: in areas where Basque is a strong language (central dialects) the use of familiar address ( $h i$ ) may have increased, but despite efforts to revitalize tutoiement, it still remains (particularly in the feminine mode) a marked option limited to a certain type of relationship; likewise, it is also probable that in some areas of the French Basque Country (especially Low Navarre) familiar address ( $h i$ ) has been weakened due to the strength of other options $(x u, z u)$ and the decline of Basque. On the other hand, there might have been qualitative changes in terms of sociolinguistic variables influencing the use of address (for example, currently age and sex might not generate so many asymmetrical interactions) and it is also possible that some modes of address are in decline or at risk of disappearing altogether.

The sociolinguistic variables and social patterns governing the use of forms of address in Basque clearly differ from those observed in Spanish or French and are not apparently influenced by them.

In the family circle, three main sociolinguistic variables are relevant to the choice of forms of address: age, sex and kinship. Tutoiement is most widely used between brothers and sisters, but usage varies according to sex: ${ }^{12}$ many speakers of different dialects do not use feminine tutoiement (called noka), which increases the frequency of $\mathrm{T}^{-13}$ or even $\mathrm{V}-\mathrm{V}$ between brother and sister. Tutoiement is used when addressing a pet, often with the masculine T regardless of the animal's sex. In non-peer kinship relationships (parents and sons/daughters, uncles/aunts and nephews/nieces, grandparents and grandchildren) an asymmetrical combination of modes (T-V) is the prevalent pattern. However, in the same cases the relationship becomes symmetrical ( $\mathrm{V}-\mathrm{V})$ when addressing women. In contrast to other European languages, $\mathrm{V}-\mathrm{V}$ is the norm between husband and wife. This also applies to engaged couples, though with more exceptions, in which case they use T-T. V is also used in Basque to address God. Broadly speaking, then, the closer the relationship, the more frequently tutoiement is used. Thus, it is more commonly used with sons and daughters than with nephews and nieces.

12. Interestingly, in a monologue a speaker referring to himself or herself will use the feminine form if female and the masculine form if male, but when thinking introspectively without regarding themselves as an addressee, speakers of either sex tend to use masculine allocutive forms.

13. T: tutoiement (hi address); V: vouvoiement ( $z$ u address). 
Outside the family circle, five variables are relevant to the choice of modes of address in Basque. Fellowship, understood in a broad sense as frequent interaction (in work, neighborhood, town or play situations) is usually a relevant and sufficient condition for the symmetrical adoption of the familiar mode of address (T-T), which is more frequent than the polite mode $(\mathrm{V}-\mathrm{V})$. Friendship is not a necessary element, even though it does favor the use of T-T: indeed, with friendships the likelihood of T-T is greatest. The absence of these elements (fellowship or friendship) does not result in asymmetry (T-V) but rather in reciprocal polite address (V-V).

Age is another key factor in the use of modes of address in Basque: closeness in age is a necessary (though not sufficient) condition for the symmetrical use of familiar address. ${ }^{14}$ Age difference results in some asymmetries (T-V), but less frequently than in the family circle; by and large, reciprocal polite address (V-V) tends to predominate.

Sex patterns similarly to age. Shared sexual identity contributes to the use of T-T, whereas sexual difference hinders it. Between friends of different sexes, asymmetries often occur with $\mathrm{T}$ for men and $\mathrm{V}(\text { or } \mathrm{X})^{15}$ for women (T-V, T-X); in other cases, $\mathrm{V}-\mathrm{V}$ occurs. There is a notable difference in the use of the two familiar forms of address: in almost all dialects use of the feminine familiar form of address (noka) is much more restricted than the masculine (toka).

Finally, social status or rank also plays an important role. A difference in status (e.g. in the relationship between employer and employee) disfavors the use of T-T, but unlike age and sex, it does not generate asymmetries, but rather leads to the V-V option. On the other hand, class differences or socioeconomic status do not seem to play a prominent role in the use of modes of address. ${ }^{16}$ In that sense, Basque society is closer to a traditional society (Brown and Ford 1961), in which birth elements (age, sex, kinship) and early interaction play a more important role than acquired elements (wealth, knowledge, profession, social status, etc.).

In the case of Basque, the first of the diachronic hypotheses formulated by Brown and Gilman (1960) for most European languages seems to have been met: the tendency not to codify differences in power through address choice (T-V), which results in symmetric uses (T-T, V-V) selected on the basis of the solidarity axis. Although this trend shows important exceptions in the family circle, where asymmetric uses (T-V) are sometimes found, V-V is preferred where girls (daughters, nieces and granddaughters) are concerned.

14. Age (i.e., closeness in age vs age difference) is a crucial variable in the use of modes of address among native speakers, although it may be of less importance to younger people.

15. X: intermediate address ( $x u$ address).

16. With the exception of the berori mode. 
Brown and Gilman's (1960) second hypothesis does not appear to be fulfilled in the case of Basque. Based on an increasingly widespread egalitarian and democratic ideology, they postulate a generalization of the T-T option in western languages. In Basque, such an option is limited to friendship and close fellowship, or certain family relations (brothers, cousins, etc.). Differences in sex and age are still deemed an obstacle for mutual tutoiement. Thus, in contrast with the progressive generalization of tutoiement in Spanish ${ }^{17}$ - and in French, although at a different rate -, $\mathrm{V}-\mathrm{V}$ is the neuter or unmarked option in Basque for many social relations: e.g., between strangers, between customer and shopkeeper, between school principal and parent, between domestic employee and employer, between boss and worker, between teacher and student, between co-workers of different sex and often even with friends of opposite sex. The shift towards generalized $\mathrm{T} T$ is even more unpredictable in such a conservative sphere as the family.

In the use of address forms in Basque, deliberate personal choices made by speakers from a set of polite options are relevant. However, the observance of certain established social conventions apart from personal interaction strategies is also relevant, though not as much as in Japanese (Hill et al. 1986; Ide 1989): this involves asymmetric family relationships, V-V between husband and wife, T-V and $\mathrm{V}-\mathrm{V}$ in relation to age and/or sex, avoidance of generalized uses of tutoiement, etc.

\subsection{Main systems of address (western/eastern dialects) and present trends}

Although Basque is spoken in a relatively small area, it presents much dialectal diversity. The aim of this section is to account for the formal and conceptual characterization of modes of address (3.4.1), explain the main systems or types of address in different dialects (3.4.2 and 3.4.3), and underline the tendency towards a simplification of those systems (3.4.4). ${ }^{18}$

17. According to the Real Academia Española $(2009,1251)$, the spread of $t u$ is the most characteristic feature of the evolution of these two pronouns [tú/usted] throughout the twentieth century. In the same way, Sampedro's investigation $(2016,37)$ begins with the premise that in Castilian Spanish the unmarked form for the pronominal expression of the second person is tú. And Silva-Corvalán and Enrique-Arias $(2017,259)$ reach the same conclusion when analyzing the Spanish of America.

18. The data of this research reflects the usage patterns of address among native speakers of the different dialects in the 90's. With respect to the use of modes of address in current standard Basque the following should be taken into consideration:

a. In standard Basque there is a smaller diversity of modes of address: basically, non-allocutive $z u(\mathrm{~V})$ and $h i(\mathrm{~T})$ are the main options; the deferential mode of address (berori) is hardly used, just like the rest of the allocutive modes of address of Eastern dialects.

(continued) 


\subsubsection{Allocutivity and modes of address}

"Allocutivity" and mode of address are concepts that pertain to different levels. Allocutive verb agreement is, in principle, a purely grammatical phenomenon: it implies the presence of a second-person marker, without the addressee participating in the action or being an argument of the verb. The concept of "mode of address" is related to social behavior and linguistic politeness, and is used here to denote a linguistic combination of pronominal and verbal forms used for addressing that indicates a certain degree of social distance or personal solidarity with respect to the addressee.

While allocutivity is a grammatical phenomenon, it is also a variable to be considered when formally characterizing the different modes of address (Rebuschi 1984, 531). In Table 6, two defining characteristics of modes of address in Basque are considered: (a) the pronoun of address selected (second person referential) and its corresponding verb (second column); (b) the theoretically possible combinations of each of the pronouns with allocutive $(+)$ or non-allocutive $(-)$ verbs (third person referential in the third column). The fourth column shows the different modes of address in Basque (rows 2-7) and the non-existing possibilities: as explained later, there is no familiar mode of address ( $h i$ ) that is non-allocutive (row 1); and there is no deferential mode of address (berori) that is allocutive (row 8).

The possibility of having allocutive berori (row 8 of Table 6) is not realized in any dialect. Likewise, the familiar non-allocutive mode of address ( $h$ i) (row 1 in Table 6) has never been attested in any dialect, although examples can be found in some literary texts (Alberdi 1996, 394-395). These rare literary examples may be due to a prejudice against the familiar allocutive conjugation ( $h i)$. In any case, all our informants refute the possibility of a non-allocutive familiar mode and the best literary tradition points in the same direction.

b. The same sociolinguistic variables (Section 3.3) are involved, although a favorable attitude to the use of symmetrical familiar address (T-T) is observed, putting aside momentarily traditionally important variables such as gender and age difference. This is probably influenced by the dominant egalitarian ideology and the predominant patterns in current Castilian and French.

c. The allocutive verbal paradigms of the hi mode of address were standardized in 1994 (much later than the rest of the verbal system).

d. Several campaigns have been carried out to revitalize or recover the use of the familiar mode of address ( $\mathrm{T}$ ) in standard Basque (Goenkale television series, literature, television, Basque academies for adults...).

e. Despite the efforts made, I conclude that the use of the familiar mode of address ( $h i$ ) has barely spread among the new Basque-speakers, to a large extent due to the difficulty involved in mastering the allocutive verbal paradigms. In the educational system, for example, except in areas where the use of Basque and $h i$ is widespread, students learn non-allocative verbal paradigms (i.e., non-allocutive $z u$ ). 
Table 6. II person pronouns and allocutivity: Theoretical and actual modes of address

\begin{tabular}{|c|c|c|c|c|}
\hline & $\begin{array}{l}\text { II PERSON REFERENTIAL } \\
\text { IZAN (“TO BE"): } \\
\text { "YOU ARE" }\end{array}$ & \multicolumn{2}{|c|}{$\begin{array}{l}\text { III PERSON REFERENTIAL } \\
\text { IZAN (“TO BE"): } \\
\text { "HE/SHE IS" +/- ALLOCUTIVE }\end{array}$} & MODE OF ADDRESS \\
\hline 1. & hi haiz & hura da & - & $\varnothing$ \\
\hline 2. & hi haiz & hura duk/n & + & allocutive $h i$ \\
\hline 3. & zu zara & hura da & - & non-allocutive $z u$ (neuter) \\
\hline 4. & zu zara & hura duzu & + & allocutive $z u$ \\
\hline 5. & xu xira & hura da & - & non-allocutive $x u$ \\
\hline 6. & xu xira & hura duxu & + & allocutive $x u$ \\
\hline 7. & berori da & hura da & - & berori \\
\hline 8. & berori da & ${ }^{\star}$ hura du & + & $\varnothing$ \\
\hline
\end{tabular}

At this point, we might ask if the feature [+/-allocutive] is pertinent to the distinction between modes of address not only from a formal point of view but also from a sociopragmatic one. That is to say, we are interested in determining whether any dialect presents an opposition between modes of address like the ones listed below ( 5 a versus $5 b$; $6 a$ versus $6 b$ ).

(5) a. $x u[-$ allocutive] versus

b. $x u$ [+allocutive]

(6) a. $z u$ neuter [-allocutive] versus

b. $z u$ [+allocutive]

According to our data, at present the opposition $(5 a) /(5 b)$ does not exist in any dialect: $x u$ [-allocutive] and $x u$ [+allocutive] alternate depending on dialectal variety, but no dialect uses both with contrasting sociopragmatic values.

Regarding the opposition (6a)/(6b), Bonaparte (1869) referred to the $z u$ allocutive mode of eastern dialects as "respectful". But this mode of address is no more respectful than the default $z u$ of western and central dialects. The two patterns $z u$ [-allocutive] and $z u$ [+allocutive] do not contrast today as modes of address in any single dialect. Instead, they present a complementary dialectal distribution: in south-western and central dialects only non-allocutive $z u$ is used; in eastern dialects, only $z u$ [+allocutive] is used as a mode of address.

In the dialect that was spoken in the Erronkari valley until it became extinct in the twentieth century, the default $z u$ mode (i.e., the non-allocutive mode) indicated greater social distance than the allocutive. According to Artola (1991, 251), in the variety of Basque spoken in Uztarroz (Erronkari) four modes of address were distinguished: (a) the $h i$ mode, used between brothers; (b) the allocutive $z u$ mode, used between people who are less intimate; (c) non-allocutive $z \mathcal{u}$, used to address parents, grandparents, the priest, etc.; (d) the berori mode (hori variant) 
used to address, for example, a very elderly person. This is compatible with Azkue's $(1932,241)$ claim that allocutive $z u$ in the Erronkari valley is a familiar mode, and explains why some informants say they have two yous for familiar address.

In the Low Navarre subdialect, some speakers are aware of the marked status of the allocutive $z u$ mode. When speaking to Basque speakers from other regions, they therefore resort to unmarked $z u$ [-allocutive] as an adaptation to their interlocutor's speech. Strictly speaking, those cases cannot be regarded as different modes, even though each register $(6 \mathrm{a} / 6 \mathrm{~b})$ has a different pragmatic value. So, in this dialect both modes coexist (allocutive $z u$ and non-allocutive $z u$ ), albeit not always as forms of address in the strict sense.

In the Zuberoan dialect, it seems that in everyday personal exchanges the neutral non-allocutive $z u$ mode is not used. This register is limited to church sermons, radio, literature and other genres lacking a definite addressee.

When a sociopragmatic opposition between the allocutive and the non-allocutive $z u$ modes applies (as in the Erronkari dialect, in the eastern part of Low Navarre and in Zuberoan), allocutivity is linked to a higher degree of familiarity or intimacy (Rebuschi 1984, 516, 539), while the absence of the allocutive is linked to greater personal or social distance (Azkue 1923). It is reasonable to think that the constant presence in conversation of allocutive markers referencing the addressee serves the purpose of signalling a closer relationship.

In conclusion, allocutivity and modes of address are concepts that belong to different levels: grammar ${ }^{19}$ and linguistic politeness respectively. It is true that in certain dialects and subdialects the feature [+/-allocutivity] can be relevant from a sociopragmatic perspective, as has happened in the past in the Erronkari dialect, but nowadays allocutivity is no longer useful to differentiate modes of address.

\subsubsection{Dialectal distribution of modes of address}

The allocutive $z u$ and $x u$ modes are a significant distinguishing feature from a dialectological perspective. Apparently, this feature provided one of the main isoglosses considered by Bonaparte (1869) for his classification of Basque dialects (or rather, the eastern dialects). The different modes of address according to dialect will now be reviewed.

In the southern dialects (Table 7) there are three forms of address (allocutive $h i$, neuter $z u$ and berori); but the third deferential register (berori) is almost extinct. The

19. The evidence that allocutivity is a strictly grammatical phenomenon is as follows: (a) choice of the hi mode necessarily implies the use of allocutive forms; (b) in the hi mode, both allocutive forms (in main clauses) and non-allocutive forms (in subordinate clauses) may occur in the same sentence. 
result of this loss is a system similar to the western and central Lapurdian-Navarrese (LN) one with only two levels for a large area (Table 8), although many speakers of these varieties only use the non-allocutive mode of address, as we remarked above.

Table 7. Southern dialects: Western, Central and Navarrese
$h i$ [+allocutive]
$z u$ [-allocutive]
berori (no longer used)

Table 8. Dialect: Lapurdian-Navarrese, Western and Central area
$h i$ [+allocutive]
$z u$ [-allocutive]

In some smaller dialectal variants (Table 9 and 10)), a non-allocutive use of $x u$ is possible. This use has an intermediate position between the intimacy of $h i$ and the distance of $z u$. In Aezkoa, this $x u$ mode is used between women and in the family, impinging on the space of the hi mode for women in particular.

Table 9. Dialect: Lapurdian-Navarrese, Hazparne

$$
\begin{aligned}
& h i \text { [+allocutive] } \\
& x u \text { [-allocutive] } \\
& z u \text { [-allocutive] }
\end{aligned}
$$

Table 10. Dialect: Navarrese, Aezkoa

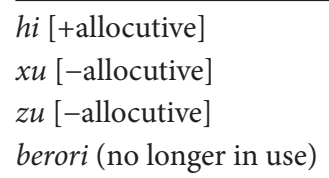

In much of the eastern Lapurdian-Navarrese dialect (Table 11), there is also an intermediate mode (allocutive $x u$ ) that is very much alive and often takes the place of its informal and formal counterparts ( $h i$ and $z u$ ). In the variety spoken in Garazi, $x u$ is the customary mode of address among family members and acquaintances whatever the addressee's gender, whereas $z u$ is restricted to formal contexts and strangers. But in other varieties (Irisarri, Heleta, Aiherra), $x u$ is gender-sensitive and rarely used when addressing men. 
Table 11. Dialect: Some areas of Eastern Lapurdian-Navarrese (ELN)

-ELN1: Irisarri, Heleta, Aiherra...

-ELN2: Garazi

$h i$ [+allocutive]

$x u$ [+allocutive]

$z u$ [-allocutive]

In some areas of eastern Lapurdian-Navarrese and Lapurdian-Navarrese (Table 12), three main allocutive modes are used $(h i, x u, z u)$. In addition, non-allocutive $z u$ is an option which can be used "mimetically" with speakers from other dialect areas in order to improve communication by reducing linguistic distance.

Table 12. Part of Eastern Lapurdian-Navarrese (ELN3): Gamarte, Oztibarre... Part of Lapurdian-Navarrese: Beskoitze, Mugerre, Urketa
$h i[+$ allocutive $]$
$x u$ [+allocutive]
$z u$ [+allocutive]
( $z u$ [-allocutive $])$

Norms of address in the Zuberoan dialect (Table 13) are similar to those in Lapurdian-Navarrese (Table 8) except that use of allocutive $z u$ is favored.

Table 13. Dialects: Zuberoan, and Eastern Lapurdian-Navarrese (ELN), Amikuze

$h i$ [+allocutive]

$z u$ [+allocutive]

In the eastern Navarrese dialect of Zaraitzu, four or five levels of address (Table 14) purportedly existed (Bonaparte 1869; Azkue 1923), but this is now difficult to confirm because the dialect is almost extinct.

Table 14. Dialect: Eastern Navarrese, Zaraitzu

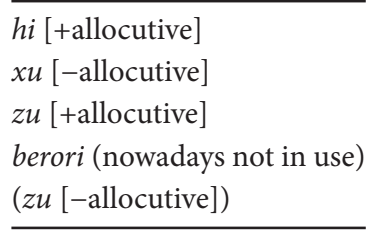

The Erronkari dialect, now extinct, had four levels of address (Table 15). 
Table 15. Dialect: Eastern Navarrese, Erronkari
$h i$ [+allocutive $]$
$z u$ [+allocutive]
$z u$ [-allocutive]
berori (no longer in use)

\subsubsection{Main systems of address according to dialect}

Mapping out the theoretical possibilities of address that are manifested in different dialect varieties, Rebuschi (1984) posited the four modes of address (A, B, C and D) listed in Table 16. Type A differentiates between two levels or registers (allocutive hi, non-allocutive $z u$ ); it is represented by Lapurdian. Type B distinguishes three levels of address (allocutive $h i$, non-allocutive $z u$ and berori), and its representatives are Bizkaian and Gipuzkoan, which are referred to in Zuazo's (2003) dialect classification as western and central. Rebuschi posits three levels for type $\mathrm{C}$, represented by Low Navarrese, with allocutive $h i$, allocutive $z u$ or $x u$, and non-allocutive $z u$. Type $\mathrm{D}$ includes two levels of address (allocutive $h i$ and $z u$ ), and the author suggests as its representative dialect the variety of Zuberoan spoken in Santa-Grazi, described by Lafon (1959).

Table 16. Modes of address according to Rebuschi (1984)

\begin{tabular}{lllll}
\hline & A & B & C & D \\
& LAPURdian & BIZKAIAN, GIPUZKOAN & LOW NAVARRESE & ZUBEROAN \\
\hline 1. $H I$ & Familiar & Familiar & Familiar & Familiar \\
2. $Z U / X U+$ alloc. & - & - & Polite & Polite \\
3. $Z U-$ alloc. & Polite & Polite & Distant & - \\
4. BERORI & - & Respectful & - & - \\
\hline
\end{tabular}

Rebuschi's types A, B and D do seem to reflect the reality of those dialects. For various reasons, however, the same is not true of type $\mathrm{C}$, which he posited for Low Navarrese. Rebuschi represents the allocutive $z u$ and $x u$ modes as options belonging to the same level (polite), but in fact they are clearly distinct and their social values differ. Moreover, the "distant" label proposed for the non-allocutive $z u$ and the hierarchy $h i<z u$ (+allocutive) $<z u$ (-allocutive) is in general inappropriate for Low Navarrese, since in most varieties both forms of address (allocutive $z u$ and non-allocutive $z u$ ) alternate geographically, but are socially equivalent. Finally, this typology only allows for a maximum of three levels of address, but evidence suggests that some dialect varieties have four levels (see Tables 12 and 15 above). 
Labels such as familiar, polite, respectful and distant can be taken as approximations when characterizing the social value of modes of address, but the relevant aspect that should be analyzed is the specific domain of social use corresponding to each.

Table 17 shows the main systems of address in present-day Basque. The hierarchy among the different modes of address in each system and their social values are depicted graphically through the use of cells of varying width.

Type I involves two modes of address based on the pronominal opposition hi/ $z u$, where the $z u$ mode can be either non-allocutive (Lapurdian-Navarrese) or allocutive (Zuberoan). In general, in almost all dialects and variants of Basque, familiar address (particularly the feminine familiar form) has a limited range of use: it is the mode a speaker uses to address himself or herself, siblings and people one has worked with for a long time, and which parents use with their children once they have reached puberty. Asymmetries are very commonplace, whether motivated by difference of sex (among siblings and friends $z u$ may be used with females and $h i$ with males) or age (especially in the family setting, where parents or uncles and aunts may use the $h i$ mode to younger relatives but get the $z u$ mode in response).

Type II, typical of southern Basque, comprises three levels in theory ( $h i<$ nonallocutive $z u<$ berori). In practice, due to the obsolescence of berori, it resembles type I.

Type III, which is distinctive of the eastern Lapurdian-Navarrese dialect of Garazi, differentiates between three levels of address ( $h i<$ allocutive $x u<$ non-allocutive $z u$ ). It is characterized by extensive use of $x u$, which overtakes the domain of familiar $h i$ almost completely (especially when addressing women). It is used throughout the family domain, where it overrides the gender factor when used to address both female and male acquaintances, and even among male acquaintances who are not close.

The consequences of this are twofold. First, in this variety the survival of familiar address is threatened by the generalized use of $x u$, which is becoming the unmarked option between acquaintances; secondly, regardless of age, $z u$ has no place in family relations and is relegated to formal spheres and interaction with outsiders.

Type IV, characteristic of certain varieties of eastern Lapurdian-Navarrese, differs from type III in two respects. The use of allocutive $x u$ is limited to family relations and mainly occurs between women addressing other women; asymmetries between sexes are common, either with $x u$ contrasting with $z \mathcal{u}$, or $x u$ contrasting with $h i$. In certain areas, when addressing speakers from other areas it is possible for allocutive $z u$ to be replaced by non-allocutive $z u$, adjusting the speaker's system (marked by allocutivity) so as to accommodate the addressee (in whose system the non-allocutive mode is the default). Hence, counting the possibility of a "mimetic" non-allocutive (marked for linguistic distance), four levels may be discerned: $h i<$ allocutive $x u<$ allocutive $z u<$ non-allocutive $z u$. 
Type V is represented by the extinct Erronkari dialect (see Table 15 above), where four different levels of address contrasted: $h i<$ allocutive $z u<$ non-allocutive $z u<$ hori (berori).

Table 17. Systems of address: Levels and use

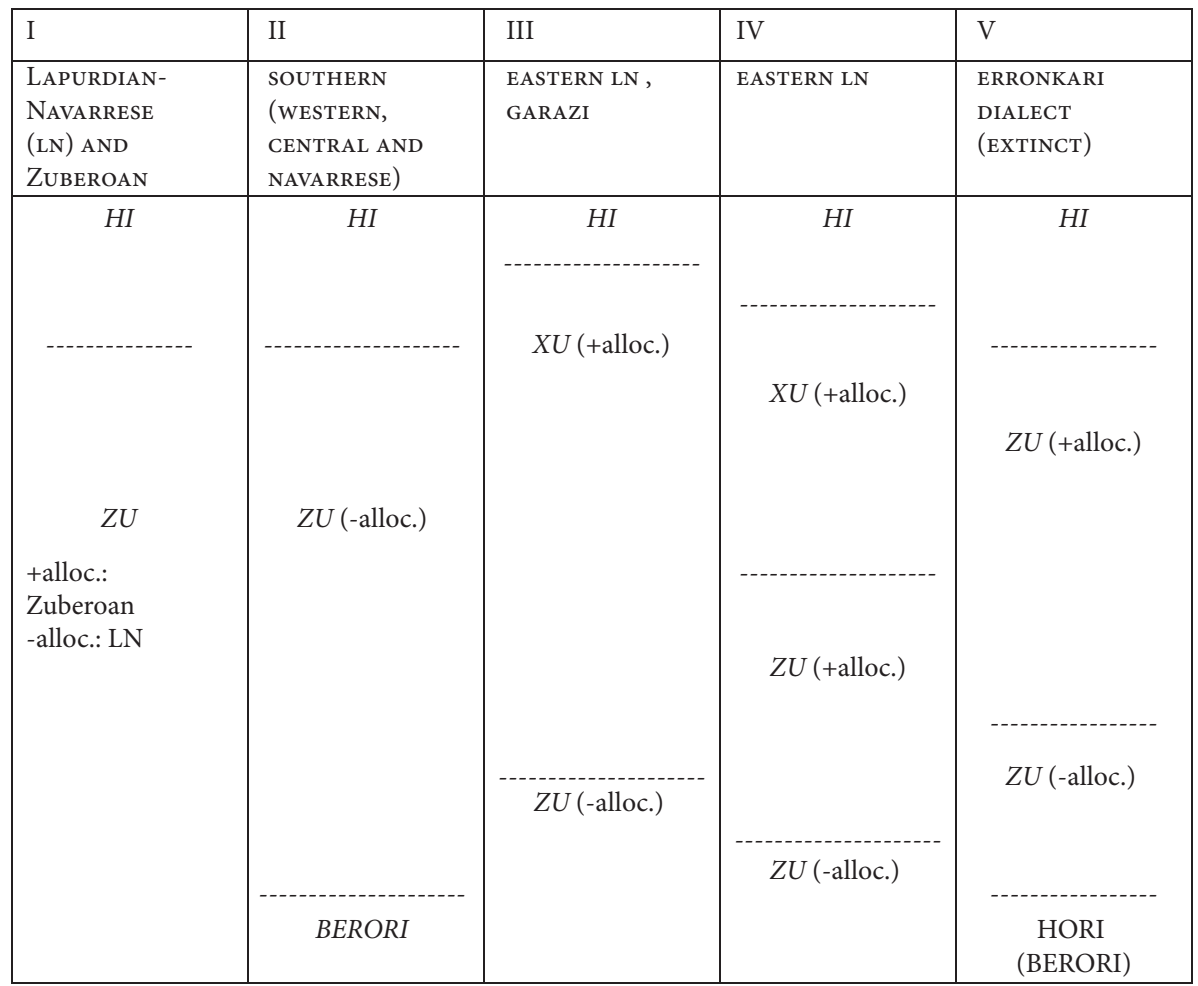

\subsubsection{Present trends: Simplification of systems}

One of the conclusions that can be drawn from Table 17 is the limited value of allocutivity to discriminate modes of address in present-day Basque, even though it is likely that the opposition $z u$ [+alloc.] / $z u$ [-alloc.] was available and meaningful in the past in some dialects (cf. the Erronkari and Zaraitzu dialects, Tables 14 and 15).

Recently there have been clear signs of a tendency towards simplification of the systems of address. Leaving aside the extinct Erronkari dialect, type IV is the only system which comprises four levels or registers. Both northern and southern Basque involve systems that have two or three levels at most.

As shown in Section 3.1 (Tables 2', $3^{\prime}$ and $4^{\prime}$ ), in all dialect varieties and types some speakers use a simplified system of address. This often occurs among native speakers of Basque and is linked to factors such as age, sex, and location (urban/ rural). The berori form is only preserved among elderly people and appears to reflect 
the customs of the past. The feminine familiar form has also disappeared from the repertoire of many native speakers of Basque because of a kind of social stigma ${ }^{20}$ attached to it in some places. So, the decline and the loss of $h i$ address is due in part in many cases to the difficulty of mastering the familiar allocutive paradigm and to a kind of social stigmatization of familiar address in some areas or among some speakers. ${ }^{21}$ In any case, it is obvious that the familiar mode of address is better preserved in non-urban areas: the rural/urban dichotomy and population movements from rural to urban areas explain the decline of some forms of address such as hitano $(\mathrm{T})$. This decline progressed steadily throughout the twentieth century, and was accentuated by industrial development and the concentration of bilingual populations in urban areas.

The Autonomous Community of Navarre has witnessed a notable spread of bilingualism among young people. Throughout the whole Basque-Spanish territory, many young people have acquired standard Basque through the education system rather than via intergenerational transmission. ${ }^{22}$ Typically, these young learners achieve basic competence in standard Basque, but fail to acquire full mastery of the augmented paradigm of conjugation required by the allocutive $h i$ mode. ${ }^{23}$ This factor is an additional obstacle to an expansion of the already weakened familiar mode of address. ${ }^{24}$ Moreover, when native Basque speakers interact with new speakers, they often avoid the familiar allocutive mode so as not to hinder communication.

20. Historically (Azkue 1923) in some places this familiar mode of address ( $h i$ ) did not have a very good reputation or was considered to be a way of speaking typical of rural areas or of "gypsies". Something similar happens in Chile with respect to voseo (Bishop and Michnowicz 2010).

21. On the other hand, there are quite a few speakers (native and non-native) who look favorably on the familiar mode of address and wish to use it, but the lack of mastery of the allocutive paradigm leads them not to.

22. As Azkarate posits $(2012,120)$ : "It is additionally important to bear in mind that the mother tongue of 30.2 percent of bilinguals is Spanish or French; they are the "new Basque-speakers" (euskaldun berriak), those that have learned Euskara in school or in adult classes (in adult education schools that teach Basque, known as euskaltegiak). And the majority of bilingual young people in the BAC are "new speakers'”"

23. The Basque Language Academy established a standard verbal paradigm of familiar address (allocutive and non-allocutive) in 1994 with the aims of promoting use of the familiar mode of address and stemming its loss. This proposal has been effective mainly in cultivated speech (such as literature and television) but has had less impact on spontaneous colloquial usage. http://www. euskaltzaindia.eus/dok/arauak/Araua_0014.pdf

24. Due to this grammatical difficulty, and in order to promote its diffusion, there have been a few proposals throughout the twentieth century to simplify the familiar mode of address (hitano) by suppressing the use of allocutive forms: that is to say, restricting it to the use of verb forms in which the second person singular is an argument of the verb. 
In the French-Basque Country, as the result of a lack of linguistic policy, the bilingual population shrank during the period under consideration. At present, most bilingual speakers are to be found among the elderly part of the population. Consequently, the use of Basque has decreased, and with it the use of certain forms of address. The tenet that a language cannot survive without family transmission (Fishman 1991) is probably also applicable to the survival of forms of address, especially allocutives, which are rarely fully mastered by Basque learners.

Thus, in varieties of type I and II many speakers use a single mode of address (non-allocutive $z u$ ), while some use two (masculine familiar, non-allocutive $z u$ ). This is in part due to the obsolescence of the berori mode in southern Basque in the course of the twentieth century, itself explained partly by its suggestion of asymmetry clashing with a more egalitarian ideology, and partly by the fact that the earlier innovation it represents had not taken root everywhere. The simplification of the systems of address is also the result of the fact that speakers are unsure of the familiar allocutive conjugation paradigm, along with the social stigmatization of familiar address. Because of that stigma, use of the feminine familiar form has declined in many areas; hence asymmetry in the use of $h i-z u$ by different sexes has increased.

All speakers of type III use the $x u$ and $z u$ modes but some do not have the familiar mode (especially in the feminine variety). A similar phenomenon is found among speakers of type IV.

From the nineteenth century on, in certain areas of eastern Lapurdian-Navarrese allocutive $z u$ has gradually been replaced with non-allocutive $z u$. This trend is likely to become more pronounced owing to the increased use of standard Basque in education and the media. However, that change does not imply a loss of registers, given that both forms (allocutive $z u$ and non-allocutive $z u$ ) are sociopragmatically equivalent.

In brief, it can be asserted that in Basque there are two macro-systems of address due to the current trend towards simplification: that used in most dialects, consisting of types I and II, where there are two levels of address $(h i<z u)$; and the Lapurdian-Navarrese system (types III and IV), based on a three-way contrast of second-person pronouns $(h i<x u<z u)$.

Everything seems to indicate that, looking towards the future, $h i$ is the weakest mode in all dialects: in Lapurdian-Navarrese, due to the vitality of the $x u$ form, and, in the rest of the dialects, owing to the marked character of $h i$ and the decline in its use in the last decades, alongside the learning difficulty presented by the allocutive verbal paradigm for speakers for whom it is not part of their native dialect. Moreover, given the increase in standardization and the revitalization process of the Basque language over recent years and based on the fact that new generations have learnt the language at school, in sociolinguistic terms it is not inappropriate to assume that non-allocutive $z u$ could become the neutral mode of address in the future for most speakers, as many of them only use that register. 


\section{Conclusions}

Despite its limited geographical extension and small number of speakers, Basque presents considerable dialectal diversity. This paper characterizes the main systems of address based on two main factors: second-person pronouns of address and the allocutive or non-allocutive form of the verb. Five types or systems of address are proposed, varying by dialect. Differences of social level are established for each system.

Modes of address in Basque present several similarities with those in Indo-European languages with respect to the pronominal system and its evolution: singularization of an originally plural pronoun; introduction of a new third-person pronoun, berori, with deferential value. The new third-person pronoun (berori) is an innovation restricted to the Basque-Spanish territory that did not spread to the Basque spoken in France. In southern (with $h i<z u<$ berori) and northern (with $h i<x u<z u$ ) dialects alike, there are thus three distinct levels of address, yet neutralization of address distinctions when addressing more than one person is the general rule in all dialects.

What makes Basque typologically interesting is the morphologization of modes of address. Noteworthy features of Basque include allocutivity in the verbal paradigm; a gender distinction reflecting the sex of the addressee in second-person familiar ( $h i$ ) verb forms; and the allocutive $x u$ mode in eastern Lapurdian-Navarrese, which implies grammaticalization of expressive palatalization as an identifier of this familiar form of address.

In terms of Comrie's (1976) theory of three axes and three types of honorifics, Basque stands out from surrounding languages in that, through its allocutive modes of address, it allows its speaker to express respect, familiarity or closeness of the addressee without the addressee being part of the proposition. Nevertheless, allocutivity is a grammatical agreement phenomenon that today has a limited sociopragmatic function, as it currently (unlike in the past) does not serve any purpose in any dialect to differentiate modes of address. Therefore, Basque systems of address are essentially similar to those of many European languages, in that they are based on a system of T/V pronouns of address and the speaker-referent axis.

I would like to conclude by stressing the current tendency towards simplification of modes of address in Basque due to the obsolescence of the third-person address form berori, the decline in the use of the familiar mode (especially the feminine form) in large areas and among speakers of almost all dialects, and also the difficulty presented by allocutive modes of address for new speakers who have acquired standard Basque at school. The consequence of this phenomenon, which does not find an analogue in other European languages, is the existence of groups of speakers in all dialect areas who resort to a simplified or reduced system of address. 


\section{Acknowledgements}

The research leading to these results has received funding from the European Union's Seventh Framework Programme for research, technological development and demonstration under grant agreement no. 613465 .

\section{Abbreviations}

$\begin{array}{ll}\text { A } & \text { absolutive } \\ \text { E } & \text { ergative } \\ \text { D } & \text { dative } \\ \text { AUX } & \text { auxiliary } \\ \text { AA } & \text { allocutive agreement } \\ \text { AAMAsC } & \text { allocutive agreement masculine } \\ \text { AAFEM } & \text { allocutive agreement feminine } \\ \text { AAzu } & \text { allocutive agreement, } z \text { mode } \\ \text { AAxu } & \text { allocutive agreement, } x \text { mode } \\ \text { 1-2-3 } & \text { 1st, 2nd and 3rd person } \\ \text { PL } & \text { plural } \\ \text { SG } & \text { singular } \\ \text { +alloc. } & \text { allocutive } \\ - \text { alloc. } & \text { non-allocutive } \\ \text { T } & \text { tutoiement } \\ \text { V } & \text { vouvoiement } \\ \text { X } & x u \text { mode. }\end{array}$

\section{References}

Alberdi, Xabier (Jabier). 1994. Euskararen tratamenduak: erabilera [Use of modes of address in Basque]. Ph.D. University of the Basque Country.

Alberdi, Xabier (Jabier). 1995. “The Development of the Basque System of Terms of Address and the Allocutive Conjugation.” In Towards a History of the Basque Language, ed. by Jose Ignacio Hualde, Joseba Andoni Lakarra and Robert Larry Trask, 275-295. Amsterdam-Philadelphia: John Benjamins.

Alberdi, Xabier (Jabier). 1996. Euskararen tratamenduak: erabilera [Use of modes of address in Basque: Use]. Bilbao: Euskaltzaindia.

Artola, Koldo. 1991. "Fidela Bernat anderea, euskal hiztun erronkariarra [Mrs. Fidela Bernat, a Basque Speaker from the Erronkari valley]." Fontes Linguae Vasconum 58: 247-281.

Azkarate, Miren. 2012. “The Current Situation of the Basque Language Speakers." In The Challenge of a Bilingual Society in the Basque Country, ed. by Pello Salaburu, and Xabier Alberdi, 113-135. Reno (Nevada): Center for Basque Studies, University of Nevada (Reno); Universidad del País Vasco/Euskal Herriko Unibertsitatea. 
Azkue, Resurrección María. 1923-1925. Morfología vasca [Gramática básica dialectal del Euskera]). [1969, Bilbao: La Gran Enciclopedia Vasca.]

Azkue, Resurrección María. 1932. Particularidades del dialecto roncalés. Bilbao: Ed. Vasca.

Basque Autonomous Community. Department of Education, Language Policy and Culture (2013) Fifth Sociolinguistic Survey. Vitoria-Gasteiz: Eusko Jaurlaritzaren Argitalpen Zerbitzu Nagusia. http://www.euskara.euskadi.eus/contenidos/informacion/sociolinguistic_research2011/en_2011/adjuntos/FithSociolingusticSurvey.pdf

https://www.google.es/url? sa=t\&rct=j\&q=\&esrc=s\&source=web\&cd=1\&cad=rja\&uact= 8\&ved=0ahUKEwjgjsiN3NbLAhXFshQKHUpaDpsQFgglMAA\&url=http\%3A\%2F\%2Fwww.euskara.euskadi.eus\%2Fr59-738\%2Fen\%2Fcontenidos\%2Finformacion\%2Finkesta soziolinguistikoa2006\%2Fen_survey\%2Fadjuntos\%2FIV_incuesta_en.pdf\&usg=AFQjCNGF9Y4_EkS6avX4fMTKDkdT3_wjfA

Bishop, Kelly; and Jim Michnowicz. 2010. "Forms of Address in Chilean Spanish." Hispania 93: 413-429.

Bonaparte, Louis-Lucien. 1863. Carte des sept provinces basques montrant la délimitation actuelle de l'euscara et sa division en dialectes, sous-dialectes et variétés. London: Stanford's Geographical Society.

Bonaparte, Louis-Lucien. 1869. Le verbe basque en tableaux, accompagné de notes grammaticales, selon les huit dialectes de l'Euskara..., London. Online version: http://www.ehu.eus/seg/_media/ egile/bonaparte/obra/n0885192_pdf_1_-1dm.pdf

Braun, Friederike; Armin Kohz, and Klaus Schubert. 1986. Anredeforschung: Kommentierte Bibliographie zur Soziolinguistik der Anrede. Tübingen: Gunter Narr.

Brown, Penelope; and Stephen C. Levinson. 1987. Politeness: Some Universals in Language Usage. Cambridge: Cambridge University Press.

Brown, Roger; and M. Ford. 1961. "Address in American English." Journal of Abnormal and Social Psychology 62: 375-85. Also in Language in Culture and Society, ed. by D. Hymes. (1964), 234-244. New York: Harper and Row.

Brown, Roger; and Albert Gilman. 1960. "The Pronouns of Power and Solidarity." In Style in Language, ed. by Thomas A. Sebeok, 253-276. Cambridge: MIT Press.

Brown, Penelope; and Stephen C. Levinson. 1987. Politeness: Some Universals in Language Usage. Cambridge: Cambridge University Press.

Comrie, Bernard. 1976. "Linguistic Politeness Axes: Speaker-Addressee, Speaker-Referent, Speaker-Bystander." Pragmatics Microfiche1.7: A3. Department of Linguistics. Cambridge: Univ. of Cambridge.

Fernández, Mauro; and Katharina Gerhalter. 2017. Pronombres de segunda persona y fórmulas de tratamiento en español: Una nueva bibliografía (1867-2016). LinRed 14 (2017). On line: http://www.linred.es/informacion_pdf/LR_informacion20_20170219.pdf

Fishman, Joshua A. 1991. Reversing Language Shift: Theoretical and Empirical Foundations of Assistance to Threatened Languages. Clevedon, Philadelphia, and Adelaide: Multilingual Matters.

Gardner, Elizabeth Frances, and Elmo Martin, Samuel. 1952. Honorific and Familiar Speech in Japanese. New Haven: Yale University Press.

Head, Brian F. 1978. "Respect Degrees in Pronominal Reference." In Universals of Human Language, vol. 3, ed. by Joseph H. Greenberg, Charles A. Ferguson, and Edith A. Moravcsik, 151-211. Stanford: Stanford University Press. 
Hill, Beverly; Sachiko Ide, Shoko Ikuta, Akiko Kawasaki, and Tsunao Ogino. 1986. "Universals of Linguistic Politeness: Quantitative Evidence from Japanese and American English." Journal of Pragmatics 10: 347-371. https://doi.org/10.1016/0378-2166(86)90006-8

Hualde, Juan Ignacio, and Jon Ortiz de Urbina (eds.). 2003. A Grammar of Basque. Berlin and New York: de Gruyter Mouton. https://doi.org/10.1515/9783110895285

Hummel, Martin; Bettina Kluge, and María Eugenia Vázquez. 2010. Formas y Fórmulas de Tratamiento en el Mundo Hispánico. México: El Colegio de México.

Ide, Sachiko. 1989. "Formal Forms and Discernment: Two Neglected Aspects of Universals of Linguistic Politeness.” Multilingua 8: 223-248. https://doi.org/10.1515/mult.1989.8.2-3.223

Joseph, John Earl. 1987. "Subject Relevance and Deferential Address in the Indo-European Languages." Lingua 73 : 259-277. https://doi.org/10.1016/0024-3841(87)90021-0

Lafitte, Pierre. 1944. Grammaire basque [Navarro-labourdin littéraire], corrected and revised edition, 1962, Bayonne: Editions des 'Amis du Musée Basque' et 'Ikas'.

Lafon, Réné. 1943. Le Système du Verbe Basque au XVI' Siècle. Bordeaux: Delmas (2nd ed., Zarautz: Elkar, 1980).

Lafon, Réné. 1947. "Sur la catégorie de genre grammatical en basque." Bulletin Hispanique XLIX: 373-394. https://doi.org/10.3406/hispa.1947.3104

Lafon, Réné. 1951. "Quelques traits essentiels de la langue basque." Boletín de la Real Sociedad Vascongada de Amigos del País, Año 7 : 13-24.

Lafon, Réné. 1957. "Remarques sur l'emploi du masculin et du féminin en basque." Via Domitia $4: 1-10$.

Lafon, Réné. 1959. "Place de la 2ème personne du singulier dans la conjugaison basque." Bulletin de la Société de Linguistique 54: 103-129.

Lapesa, Rafael. 1970. “Personas gramaticales y tratamientos en español.” Revista de la Universidad de Madrid 19: 141-167.

Michelena, Luis. 1961. Fonética HistóricaVvasca. San Sebastian: Publicaciones del Seminario Julio de Urquijo de la Excma. Diputación de Guipúzcoa.

Michelena, Luis. 1981. "Lengua común y dialectos vascos." Anuario del Seminario de Filología Vasca Julio de Urquijo 15: 291-313.

Moreno, María Cristobalina. 2002. "The Address System in the Spanish of the Golden Age." Journal of Pragmatics 34: 15-47. https://doi.org/10.1016/S0378-2166(00)00074-6

Oyharçabal, Beñat. 1993. "Verb Agreement with Nonarguments: On Allocutive Agreement." In Generative Studies in Basque Grammar, ed. by Jose I. Hualde, and Jon Ortiz de Urbina, 89-114. Amsterdam: John Benjamins.

Páez Urdaneta, Iraset. 1981. Historia y Geografía Hispanoamericana del Voseo. Caracas: La Casa de Bello.

Real Academia Española y Asociación de Academias de la Lengua Española. 2009. Nueva Gramática de la Lengua Española. Madrid: Espasa Calpe.

Rebuschi, George. 1984. Structure de l'énoncé en Basque. Paris: Société d'Etudes Linguistiques et Anthropologiques de France.

Salaburu, Pello, and Xabier Alberdi. 2012. The Challenge of a Bilingual Society in the Basque Country. Reno (Nevada): Center for Basque Studies, University of Nevada (Reno); Universidad del País Vasco/Euskal Herriko Unibertsitatea.

Sampedro, María. 2016. Las Formas de Tratamiento "Tú" y Uusted" en el Español Centro-Norte Peninsular: Estudio Sociolingüístico. Salamanca: Ediciones Universidad de Salamanca. 
Silva-Corvalán, Carmen, and Andrés Enrique-Arias. 2017. Sociolingüística y Pragmática del Español. 2nd edition, Washington, DC: Georgetown University Press.

Zuazo, Koldo. 1998. "Euskalkiak gaur [Basque dialects today]" Fontes Linguae Vasconum 78: 191-233.

Zuazo, Koldo. 2003. Euskalkiak. Herriaren Lekukoak. [Basque dialects. People's witnesses] Donostia: Elkar.

\section{Author's address}

Xabier Alberdi-Larizgoitia

The Department of Basque Language and Communication

Labor Relations College

University of the Basque Country (UPV/EHU)

Sarriena, 48940 Leioa (Biscay), Spain.

xabier.alberdi@ehu.eus 